\title{
Exploring Online Teachers' \\ Pedagogical Content Knowledge in Business English Teaching: A Hermeneutic Study
}

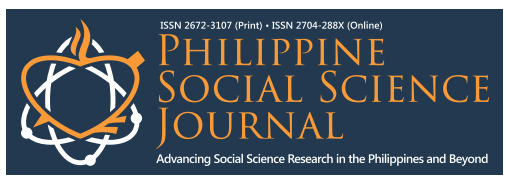

Ana Mariel Abion Moreno ${ }^{1}$ and Constantino Terrenal Ballena ${ }^{2}$

${ }^{1}$ Business English Coach, Alue Philippines Inc., Makati City, Philippines

${ }^{2}$ De La Salle University-Dasmariñas, City of Dasmariñas, Cavite, Philippines

\begin{tabular}{l} 
Article history: \\
Submitted: 12 November 2021 \\
Revised: 20 November 2021 \\
Accepted: 21 December 2021 \\
\hline Keywords: \\
Business English \\
English teaching \\
Hermeneutic phenomenology \\
Pedagogical content knowledge \\
PCK development \\
Makati City
\end{tabular}

ABSTRACT. This study explored the online Business English teachers' pedagogical content knowledge (PCK) to understand its essence in Business English teaching. It sought to uncover what they thought about PCK in Business English lessons and how they developed their PCK as they engaged themselves in the everyday teaching of Business English. Hermeneutic phenomenology was employed since the purpose of the study concerns the reflection and interpretation of the online Business English teachers' experiences. The participants of the study were six online Business English teachers from one ESL Company in the Philippines catering to business professionals. They were chosen through homogeneous purposive sampling. The data collection included in-depth interviewing following semi-structured interviews and observations to gather rich descriptions of the participants' reflection and interpretation of their experiences. The data were analyzed using the six-step data analysis of Smith et al. (2021) due to the interpretive nature of the study. The results of the analysis revealed that the online Business English teachers thought of PCK as knowledge of strategizing, knowledge of Business English as the language in the workplace, and knowledge of Business English being distinct from General English. Additionally, the findings reported that teachers developed their PCK through several sources such as their encounter in the field, growth processes, and perceived need for further PCK development in Business English teaching. A creative synthesis captures the essential themes. Despite the online Business English teachers' patent consciousness of their PCK in Business English, they still demonstrated the need to be exposed more to the business field and broaden their knowledge of business phrases and expressions. Teacher interaction with various types of students, and feedback from senior colleagues helped develop and widen their PCK in Business English.

\subsection{Introduction}

Business English communication skills are a substantial part of successful business negotiation in today's business world. Practical Business English communication skills establish a long-term success of companies in that delivering meaningful messages brings a significant impact on business scenes (Romanowski, 2015). Several national companies have already implemented Business English in their companies regardless of whether or not they have partners in English-speaking countries (Katsumura, 2011; Seidelhofer, 2010, as cited in Podboj, 2013). People who earn a high salary are the ones to claim that the English language is typically used in establishing business relationships with foreign individuals (Michaud, 2012).

The concept of Business English implies integrating the English language in business; it is different from the general English that people usually use (Podboj, 2013). It is considered part of English for specific purposes or ESP (Avsheniuk \& Seminikhyna, 2020). It covers every aspect of linguistics in business activities such as presentations, negotiations, meetings, correspondence, and oral and written reports (Kutateladza, 2014). Hyde (2013) claimed that Business English intends to address the language skills needed by professional learners in the business field. The objectives of Business English teaching vary and become diverse due to teachers who have different backgrounds and come from other fields than language (Xi, 2018). Thus, it is fundamental for Business English teachers to have specific professional skills and theoretical knowledge to easily set their goals, teaching contents, and backgrounds (Zhang, 2013).

Shulman (1986) first introduced the idea of pedagogical content knowledge or PCK to his colleagues and students. PCK is the third component of teaching knowledge and content knowledge, and pedagogical knowledge (Cochran, 1993; Solis, 2009). Moreover, PCK is the combined application

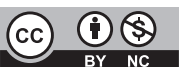

This article published by Philippine Social Science Journal (PSSJ) is licensed under a Creative Commons AttributionNoncommercial 4.0 International (CC BY-NC 4.0). You are free to share (copy and redistribute the material in any medium or format) and adapt (remix, transform, and build upon the material). Under the following terms, you must give appropriate credit, provide a link to the license, and indicate if changes were made. You may do so in any reasonable manner, but not in any way that suggests the licensor endorses you or your use. You may not use the material for commercial purposes. 
of subject matter knowledge and teaching strategy and methodology (Shulman, 1986; Liu, 2016). As Cesur and Ertas (2018, p. 124) put it, PCK demonstrates teachers' knowledge of relating "what they know about what they teach" to "what they know about teaching." Loughran et al. (2012) argued that teachers' PCK is developed as they continue to experience it in their teaching lives. PCK is "the most fundamental element of teachers' knowledge," so it has gained popularity among researchers (Guerriero, 2014, p. 5).

PCK has garnered attention among researchers, and studies in different areas have been conducted recently, focusing on the field of Science and Mathematics (Baumert \& Kunter, 2013; Kultsum, 2017; Melo et al., 2020) and highlighting teachers' knowledge of curriculum and strategies for teaching. However, according to Evens et al. (2015), Shulman (1986) designed PCK for all subject areas. For example, De Loreto et al. (2019) conducted a study involving new social studies teachers in the Philippines and found out that one of the five challenges is the lack of pedagogical content knowledge. In contrast, adopting the concept of Shulman (1986)'s PCK and examining the perspective of English teachers in Turkey, Atay et al. (2010) revealed that teachers' theoretical knowledge gained in their methodology course helped them improve their PCK. Liu (2016) and Pientka (2012) revealed that mentors used their personal experiences in constructing their PCK. In addition, the study of Faisal (2015) showed that Indonesian English teachers' PCK, which consisted of their knowledge of the content, knowledge of pedagogy, knowledge of learners, and knowledge of the curriculum, was central in efficiently developing their junior high school students' written English. On the other hand, Wu et al. (2019) underscored teachers' knowledge of the purpose of Business English instead of knowledge of content. In a more recent study by Lyu et al. (2021), PCK, through the Chinese College English teachers' views on knowledge, was investigated. It was revealed that teachers could know the subject matter they teach but not the teaching methods and strategies they employ. Relatively, PCK was seen to develop through practice even without teacher training (Nind, 2020).

Despite the various studies conducted about Business English, its curriculum, and the teachers' knowledge and skills, Grossman (1990 as cited in Cesur \& Ertas, 2018, p. 124) claimed that "teachers' pedagogical content knowledge in teaching English is still an understudied area". Additionally, for Business English, most studies conducted were in China and universities in other countries. However, language centers like the ones in the Philippines have not been thoroughly investigated. Bhatia and Bremmer (2012 as cited in Peng, 2013) said that only a few studies in Business English had been conducted. A more recent study by Wu et al. (2019) highlighted the limited studies on PCK, which focused on online Business English teachers and Business English teaching. They emphasized the need to study how PCK is integrated into Business English teaching. Most studies investigated the PCK of teachers at the secondary school level (Jones \& Moreland, 2015) but not the PCK of teachers belonging to language centers catering to professional learners. Hence, the present study was undertaken to understand online English teachers' PCK in Business English teaching. This study could add to the few PCK studies on Business English teaching.

This study sought to explore the lived experiences of online Business English teachers and their understanding of PCK in Business English teaching. Specifically, it answered the following questions: (1) what did teachers think about pedagogical content knowledge in Business English lessons; and (2) how did the pedagogical content knowledge of teachers develop as they engaged themselves in the everyday teaching of Business English?

\subsection{Framework of the Study}

Phenomenology was employed in this study since it sought to describe, interpret, and understand the phenomenon under investigation based on the participants' perceptions. Phenomenological research investigates how participants who experience the phenomenon give meaning to these experiences (Patton, 2014; Taylor et al., 2015). Its goal is to explore the participants' "life-worlds" and determine how they create their meanings from their lived experiences (Burke \& Larry, 2014). The present study utilized hermeneutic phenomenology since it is vital to know how the participants make sense of their experience through the interpretation and meaning they associate with it. "Transforming lived experience into a textual expression of its essence" is the goal of phenomenology (Van Manen, 2016, p. 36). As readers read the detailed description of the participants' accounts, they could have a vivid image of what it is like to teach Business English with teachers' pedagogical content knowledge. 
In the present study, the participants' lived experiences were transformed into a textual expression of their essence. The rich data constituting the lived experiences of the participants were subject to interpretive analysis (Smith et al., 2021) in light of hermeneutic phenomenology resulting in the essence of such experiences.

\subsection{Methods}

Research Design. This qualitative study used hermeneutic phenomenology as its research design since it sought to understand pedagogical content knowledge in Business English, including its development based on the online teachers' reflection of their experiences. According to Van Manen (2007), phenomenology concerns human reflection and interpretation of experience; thus, thoughtfulness in reflecting on the experience is essential (Smith et al., 2021). Hermeneutic phenomenology enabled the researchers to incorporate their interpretation of the explored experiences of the participants using their understanding of the phenomenon (Ajjawi \& Higgs, 2007). Despite the researchers' involvement, knowledge, and experience about the phenomenon explored, credibility was established through the different techniques explained by Lincoln and Guba (1985). On the one hand, through hermeneutic phenomenology, our experiences form into descriptions "will be effective to analyze pedagogical aspects" of things that occur in the class since it includes the description of both external and internal experience (Fuster Guillen, 2019, p. 221).

Participants and Sampling. The participants of this study were six online Business English teachers, called coaches, from one ESL Company in the Philippines that caters to business professionals called trainees. The six participants were the only senior coaches left in the remote team. Smith et al. (2021) and Creswell (2013) recommended a small sample size with three to ten participants since an interpretive study aims to provide a detailed description of each participant's lived experience. The participants were selected through purposive sampling, specifically homogenous sampling. They were selected based on the following criteria: language center teacher, types of learners being handled, length of Business English teaching experience, work status, and willingness to participate in the study. Pseudonyms were assigned to each participant to protect their identity and ensure confidentiality.

Data Collection Techniques and Procedure. In-depth interviewing and observation were the data collection techniques employed in the present study. Following the semi-structured interviewing, the participants were asked to "tell their stories in their own words" (Smith et al., 2021, p. 84) and give meaning to their experiences of pedagogical content knowledge in Business English teaching through their reflections. The researchers developed and used an interview protocol with ten main questions following the recommendation of Creswell and Poth (2016), although follow-up questions were given in the actual interview. Interview sessions were conducted online via Zoom and Gmail since these were the most convenient online meeting platforms available to all the participants. Interviews ran for forty-five to sixty minutes for each participant. Likewise, asynchronous email interviewing was employed in the study in light of Ratislavova and Ratislav (2014) and James and Busher (2009). This data collection procedure was repeated until data saturation was reached. With the explicit permissions of the participants, all the interview sessions were recorded and later transcribed for purposes of data analysis.

Relevant data constituting the participants' lived experiences were also collected through observation, which was done after the first interview session with each of the six participants. The researchers' observation was undertaken to see if the participants' descriptions of their experiences correlated with their behavior or actions in their respective classes. The researchers also developed an observation protocol that guided them during the notetaking of information while observing the teachers' online teaching. The main focus of the protocol was on the participants' language use, vocabulary expressions, and teaching strategies. Observations were done twice for each participant using the video recording of classes to avoid distracting class discussions. During the observations, the researchers took note of different activities happening in the class, including but not limited to the teachers' teaching method, language use, and vocabulary expressions. The observation protocol played a big part in stressing the important data to be considered and written down. It was also helpful in presenting the chronology of activities in the scene observed (Creswell \& Poth, 2016).

Analysis of Data. The interview transcripts and observation data were analyzed following the sixstep data analysis of Smith et al. (2021): (1) Reading and re-reading, (2) Initial noting, (3) Developing emergent themes, (4) Searching for corrections among emergent themes, (5) Moving to the next case, and (6) Looking for patterns across cases. 
The data analysis began with the researchers' familiarization and involvement in the original data transcripts by reading and re-reading them. Following the recommendation of Smith et al. (2021), the researchers listened to the audio recordings of the interviews while reading the transcript to imagine the participants' voices. Similarly, the observation data were read and reviewed for familiarization and as a reminder that the participants' experiences were the focus of the study. After reading the first participant's transcript, the researchers noted significant responses to interview questions. Following the suggestion of Smith et al. (2021), a Microsoft Word file with four columns containing the original script, initial comments, emergent themes, and research questions was used.

In developing the emergent themes, the researchers reduced the data without neglecting the connections of patterns in the exploratory notes. Themes were noted and expressed in phrases and interpreted. The generated themes were read and re-read to identify the connections between and among the emergent themes until a list of themes was made. Finally, the researchers looked for patterns across cases. Significant connections of the themes were generated from each case, and their shared qualities were examined. This was done by creating a master table of themes from different cases. Another Microsoft Word file was created where the themes were renamed and relabeled. In this step, the data from the two data collection techniques, interviews and observations, were compared resulting in the generation of the final list of themes.

Trustworthiness of the Study. In a qualitative study, it is essential to establish the trustworthiness of the findings, so the recommendations provided by Lincoln and Guba (1985) were considered in this research. Triangulation helped validate the findings by comparing the data from interviews and observations. Triangulation is necessary to maintain the consistency of the findings to "increase the confidence in the confirmed patterns and themes" (Patton, 2014, p. 240). Additionally, peer debriefing was employed, and it allowed the researchers to see other meanings they did not notice. Peer debriefers helped the researchers become aware of the "taken for granted biases, perspectives, and assumptions" (Lincoln \& Guba, 1985). The peer debriefer in this study was once a Business English teacher and a colleague of one of the researchers, but she now works in another industry. The peer debriefers provided significant comments and suggestions to the researchers about analyzing the transcripts and notes. It made the researchers notice some participants' utterances that had an essence in the data analysis. The above strategies were done to ensure the validity of the findings at the end of this study.

For ethical considerations, all the participants gave freely their consent to participate in the study after explaining to them the purpose and value of the present study. They were assured that their anonymity and the confidentiality of their responses throughout the entire conduct of the research until its publication and post-publication would not be breached following the data privacy law and pertinent laws.

\subsection{Results}

\section{What teachers thought about PCK?}

Three final themes emerged in relation to the first specific research question. These themes were PCK as the knowledge of strategizing to deliver lessons effectively, PCK as the knowledge of Business English as the language in the workplace, and PCK as the awareness of Business English teaching being distinct from General English. These themes and their corresponding subthemes are presented in Table 1.

\section{Theme 1: PCK as the knowledge of strategizing and delivering lessons effectively.}

The first theme highlighted the awareness and consideration of the students' needs and attention to their culture and background. The results showed that the online Business English teachers described their teaching approach as dependent on their students' needs and understanding. For instance, the majority of the online Business English teachers explained that beginner learners often received lessons and discussions with grammar involvement, whereas intermediate and advanced students primarily performed interactive activities with a focus on the use of vocabulary and expressions. This is illustrated in the first extract below.

Extract 1:

Participant A: ... if a student is assessed as a beginner, he or she will be given simple activities only like grammar activities to enhance sentence construction. On the other hand, if students are assessed as intermediate or advanced, we focus on their interactions in various business situations. 
Table 1. What teachers thought about PCK?

\begin{tabular}{ll}
\hline Themes & Subthemes \\
\hline $\begin{array}{l}\text { PCK as the knowledge of strategizing to } \\
\text { deliver lessons effectively }\end{array}$ & $\begin{array}{l}\text { Awareness of and consideration } \\
\text { of the learners' needs } \\
\text { Attention to students' culture } \\
\text { and background }\end{array}$ \\
$\begin{array}{ll}\text { PCK as the knowledge of Business English } \\
\text { as the language in the workplace }\end{array}$ & $\begin{array}{l}\text { Business-like manner of } \\
\text { presenting oneself } \\
\text { Discussions and activities } \\
\text { reflecting business situations }\end{array}$ \\
PCK as the awareness of Business English & $\begin{array}{l}\text { Use of teaching approach } \\
\text { suitable for professional learners } \\
\text { teaching being distinct from General } \\
\text { English }\end{array}$ \\
\hline
\end{tabular}

The online Business English teachers were also challenged to come up with teaching strategies to make their lesson delivery smooth. The results also revealed the necessity for online Business English teachers to know their students' culture and background in relation to their teaching strategies. This is manifested in the extract that follows.

Extract 2:

Participant A: Whenever I talk to them ... I ask them about their culture not only in Japan but the company culture as well.

With all the participants' narratives of their daily lived experiences on the essence of knowing the culture and background of the students, it was apparent how they used those ideas to apply appropriate teaching approaches.

\section{Theme 2: PCK as the knowledge of Business English as the language in the workplace.}

The second theme underscored how teachers presented themselves in a business-like manner even outside the business scenes to stress the nature of the English language in the workplace. The online Business English teachers taught students to present themselves professionally in business and non-business situations. Therefore, identifying the situation and the roles to portray was important as illustrated in the extract below.

Extract 3:

Participant D: At our company, we are not only teaching them business matters alone.

We are also trying to make ... [them] differentiate formal and casual situations.

Moreover, results showed that the online Business English teachers shared various types of lessons and activities. Discussions and activities reflected business situations. Some of these business situations were attending meetings, negotiating, making a proposal, and doing presentations. They are exemplified in the following excerpts:

Extract 4:

Participant A: We also have classes like meetings, negotiation, and anything that could help them to learn more about communicating English in a business situation.

\section{Extract 5:}

Participant C: I think facilitation and negotiations, especially for salespersons, are also very important. Ah, making a proposal, I think, even if the student is just a member of a specific department, making a proposal is important.

The business situations presented in the foregoing were explained and described by the online Business English teachers in the interviews, and these were also found in the observation notes. 


\section{Theme 3: PCK as the awareness of Business English teaching being distinct from General English.}

The data from the online Business English teachers' rich accounts unveiled their awareness of the distinct features of Business English from General English. They talked about their mindfulness of a teaching approach applicable to their students, considering that they were adult professionals. This is shown in extract 6.

\section{Extract 6:}

Participant F: In this case, if we look at Business English as an approach to how we use English. It's like how we should communicate with professionals ... and they are already professionals. That's why when we are teaching business English, we are not focusing on grammar.

When asked about their idea of Business English, many of them perceived it to be the use of business terms applicable to specific business situations. It was also written down in the observation notes that varieties of expressions for some business situations were used by the online Business English teachers.

\section{How teachers developed their PCK?}

Three final themes were generated to answer the second research question, which focused on how teachers developed their PCK. These were challenges attendant to their Business English teaching experience, the growth process of teachers' PCK in Business English teaching, and consideration for further PCK development in Business English teaching as shown in Table 2 with their respective subthemes.

Table 2. How teachers developed their PCK?

\begin{tabular}{ll}
\hline Themes & Subthemes \\
\hline $\begin{array}{l}\text { Challenges attendant to their Business } \\
\text { English teaching experience }\end{array}$ & $\begin{array}{l}\text { From challenges to learning and satisfaction } \\
\text { From teaching adjustment to comfortability }\end{array}$ \\
$\begin{array}{l}\text { The growth process of teachers' PCK } \\
\text { in Business English teaching }\end{array}$ & $\begin{array}{l}\text { Continuous experience and interaction with } \\
\text { students } \\
\text { Senior colleagues' significant experience } \\
\text { and advice } \\
\text { Continuous self-learning and discovery }\end{array}$ \\
$\begin{array}{l}\text { Considerations for further PCK } \\
\text { development in Business English } \\
\text { teaching }\end{array}$ & $\begin{array}{l}\text { Knowledge of students' industry and } \\
\text { specialization }\end{array}$ \\
\hline
\end{tabular}

\section{Theme 4: Challenges attendant to their Business English teaching experience.}

Throughout the interviews, the online Business English teachers were able to richly share the challenges they encountered and how these challenges were transformed into a learning experience and teaching satisfaction. One of the challenges they encountered was the need for them to be mindful of their teaching approach, considering that they had a different set of students. This is evident in the extract that follows.
Extract 7:
Participant D: . . . even though I'm an English major, I still find it challenging because
I cannot use simple terms or my sentence should be simple as possible so that a person can understand that clearly without misinterpretation, so definitely my business English teaching experience is unique.

On the other hand, the online Business English teachers gladly said that those challenges led them to more learnings. Most of them were satisfied to teach a subject matter different from their 
background because they had the opportunity to learn more. Aside from the challenges that led to learning and satisfaction, teaching adjustment leading to comfortability transpired.

\section{Theme 5: Growth process of teachers' PCK in Business English teaching.}

The present study revealed that the online Business English teachers thought they specifically improved their PCK through their experience and interaction with their students. Through the daily teaching engagement and student interaction the online Business English teachers had, they developed their PCK in Business English teaching. Moreover, they developed their PCK by sifting through the experiences that senior colleagues shared and the advice they gave, as exemplified in the following excerpt:

Extract 8:

Participant A: In my current company, I am able to develop my skills through the help of my mentors and supervisors. They teach me the right procedures and techniques in teaching Business English.

Experience, students, and colleagues were of great help to the online Business English teachers in improving their knowledge of the content they taught and their knowledge of effective lesson delivery. They also confidently shared how their self-initiative to learn supported them in developing their PCK. It is shown in the subsequent extract.

Extract 9:

Participant D: I do self-study by reading business books... So, there I encounter a lot of business terms. I jot [these] down, and I try to find [their] meanings.

The online Business English teachers tried to continuously improve their PCK through experience and discovery of new ways of teaching and learning.

\section{Theme 6: Considerations for further PCK development in Business English teaching}

The sixth and final theme was on some considerations for further development of their PCK in Business English teaching. All the online Business English teachers recognized the necessity for them to stay in their current industry to experience and learn more. They also expressed their call for various trainings that are relevant to their teaching so they could improve their PCK. This was supported by the extract that follows.

Extract 10:

Participant A: Honestly, I would like to have more seminars and training about it. I mean, if somebody could really teach me more strategies and more ways to become an effective Business English teacher, I think it would be great to have seminars and training to fully develop my skills.

Based on the online Business English teachers' vivid description of their lived experiences, they were pleased with the improvement they had in their current career, although they knew they had to learn more. The different things that contributed to the online Business English teachers' PCK growth in Business English teaching were notable. Their high regard for further improvement of their PCK was explicitly demonstrated. Certainly, progress would come to these online Business English teachers due to their positive insights about Business English teaching.

\subsection{Discussion}

This hermeneutic phenomenological study explored the online Business English teachers' pedagogical content knowledge in Business English teaching. Their lived experiences convey that PCK in Business English teaching comprises knowledge of strategizing, knowledge of Business English as the workplace language, and awareness of Business English as distinct from General English.

All the online Business English teachers attributed their knowledge of their learners' needs, culture, and background in using appropriate strategies and providing lesson activities relevant to students' backgrounds. In fact, English teachers can demonstrate effective teaching by understanding the knowledge and skills needed by the students, including their culture and background, because they can adjust to their students (Mihaescu, 2013; Kultsum, 2017). Faisal (2015) considers the knowledge of the student as part of PCK in teaching the English language. Teachers improve their teaching strategies to meet the needs of students in the course (Guiyu 
\& Yang, 2016). It is apparent that meeting the needs of the students means the online Business English teachers understand their learners.

In terms of PCK as the knowledge of Business English being the workplace language, the online Business English teachers reported that Business English is about practicing their language skills through simulations of workplace situations. According to Guiyu and Yang (2016), Business English teachers should teach practical business skills that students need for their work through role-plays and simulations. This is supported by Hyde (2013), who believed that Business English intends to address the language skills needed by professional learners in the business field to apply in several business scenes. Moreover, Geng (2017) mentioned that teachers should address the students English language skills and their business knowledge skills. In the present study, business knowledge skills were dependent on the activities that reflect business situations.

On the contrary, the teaching of presenting oneself professionally even in non-business situations as part of Business English has not been seen in the existing literature. Theses literature focused on giving business situations (Guiyu \& Yang, 2016). However, it did not mention teaching the professional ways of communicating outside their cultural settings and non-business situations. This is significant to the online Business English teachers because they see the frequent involvement of their business students in other situations outside their work and their culture.

Furthermore, each Business English teacher displayed awareness of Business English as different from General English. Xi (2018) claimed that teachers should be equipped with business communication knowledge and Business English expressions and teaching strategies to provide suitable activities for learners to apply in the business world. Avsheniuk and Seminikhyna (2020) found that some English teachers feel the need to undergo some practical training programs because they are not equipped with knowledge about their learners' professional field, which could lead to difficulty in using specialized vocabulary. In the present study, the online Business English teachers were vocal about the need to equip themselves with the register of Business English for effective delivery of Business English lessons.

Additionally, the current study highlighted how the online Business English teachers associated the development of their PCK with their current Business English teaching experience and the growth process they gained from self-learning, students, and colleagues. They also shared their need for the further development of their PCK in Business English teaching. These findings were corroborated by Loughran et al. (2012), Nind (2020), and Atay et al. (2010), highlighting the experiences of teachers and feedback from colleagues in developing their PCK.

Continuous experience and staying in the same field would be important, as believed by the online Business English teachers. In line with the existing literature, like the study of Avsheniuk and Seminikhyna (2020), where teachers encountered challenges in incorporating activities relevant to the students' field, some of the online Business English teachers also saw the need for them to have teachers' training that addresses their knowledge of Business English and teaching skills for effective lesson delivery. This is similar to the findings of Pientka (2012), where the English teachers perceived training programs as helping them develop their PCK.

\subsection{Creative Synthesis}

After thorough scrutiny of the results and discussion sections of the paper, a creative synthesis was designed; it puts together the essential constructs which are pivotal to pedagogical content knowledge. The synthesis is reflected diagrammatically in Figure 1.

Figure 1 presents the components attributed by the online Business English teachers to PCK in Business English teaching. The overlapping circles demonstrate the interrelatedness of different themes that emerged from the analysis. PCK in Business English teaching is placed in the middle since it is the focus of the study. On the other hand, the three circles in color are the themes that represent the thoughts of online Business English teachers about PCK. Meanwhile, the descriptions in the arrow outside the circles point to the subthemes relevant to themes based on the accounts of the online Business English teachers. For instance, the arrow above with the subthemes on awareness of and consideration of the learners' needs, and attention to students' culture and background points to its corresponding theme on strategizing for effective lesson delivery. On the other hand, businesslike manner of presenting oneself, and discussion and activities reflecting business situations, on the right, are the subthemes pointing to Business English as the language in the workplace. The arrow on the left points to the subthemes, such as the use of teaching approach for professional learners and 
needs for business terms in business situations, which are part of Business English as distinct from General English. Furthermore, the themes are placed in another whole circle to signify the Business English context and that they are exclusive to Business English.

The PCK represented by Faisal (2015) based on Shulman (1986)'s work has four components: knowledge of content, knowledge of pedagogy, knowledge of learners' misconceptions, and knowledge of curricula. Wu et al. (2019) used the same components in their study about Business English, but with the knowledge of content replaced by the knowledge of the purpose of Business English. Significantly, in this present study, some components proposed by Shulman (1986) and framed by Wu et al. (2019) were observed by the online Business English teachers. However, these are re-categorized based on the description of the online Business English teachers' lived experiences. Moreover, there is a new subcomponent not mentioned in the existing literature, which is the manner of presenting oneself in various contexts even outside the business field. It is seen as important by the online Business English teachers based on their experience; hence, it is also worthy of recognition in PCK, especially in Business English teaching.

By and large, figure 1 could be used as a new framework in Business English apart from the one formulated by Wu et al. (2019) in that it is more specific in grouping various components and subcomponents.

\subsection{Conclusion}

Pedagogical content knowledge in Business English constitutes several components that aid teachers in delivering lessons effectively. Some of these components are knowledge of strategizing to deliver lessons effectively, knowledge of Business English as the language in the workplace, and awareness of Business English teaching being distinct from General English. In addition to the online Business English teachers' patent awareness of their PCK in Business English, exposure to the business field and increased knowledge of business phrases and expressions are deemed necessary. Lastly, teacher interaction with various types of students and feedback from senior colleagues serve as a sturdy scaffold in developing and widening their PCK in Business English.

\subsection{Limitations of the Study}

This hermeneutic phenomenological study explored the pedagogical content knowledge in Business English teaching of online Business English teachers who worked in a language center. The study only involved six online Business English teachers who are all English majors; thus, it could not present whether online Business English teachers from other fields, especially the business field, have the same notion and experience as the language teachers. Lastly, the challenges encountered by the online Business English teachers and the training that could alleviate the challenges were not explored specifically in terms of the register of Business English.

\subsection{Future Research}

Given the limitations this study has, some suggestions for future research may be carried out. First, a similar study may be conducted, but focusing on more Business English teachers from fields other than language centers. The combined perspectives of language teachers and business professionals would greatly provide meaningful and another effective framework for the PCK of Business English teachers. Second, the challenges that teachers encounter in using specialized business terms and expressions in the Business English field may be delved into for intervention purposes. Lastly, Business English teachers' interaction with various types of students may be investigated to further understand its contribution to Business English teachers' PCK development.

\section{REFERENCES}

Ajjawi, R., \& Higgs, J. (2007). Using hermeneutic phenomenology to investigate how experienced practitioners learn to communicate clinical reasoning. The Qualitative Report, 12(4), 612-638. http://www.nova.edu/ssss/ QR/QR12-4/ajjawi.pdf

Atay, D., Kaslioglu, O., \& Kurt, G. (2010). The pedagogical content knowledge development of prospective teachers through an experiential task. Procedia Social and Behavioral Sciences, 2(2), 1421-1425. https://doi. org/10.1016/j.sbspro.2010.03.212 
Avsheniuk, N., \& Seminikhyna, N. (2020). Challenges of teaching and learning business English in Ukrainian universities. Arab World English Journal (AWEJ) Special Issue on the English Language in Ukrainian Context, 68-78. https://dx.doi.org/10.24093/awej/elt3.6

Baumert, J., \& Kunter, M. (2013). The effect of content knowledge and pedagogical content knowledge on instructional quality and student achievement. Research Gate. 10. https://doi.org/1007/978-1-4614-514959.

Burke, J.R., \& Larry, C. (2014). Educational research: Quantitative, qualitative, and mixed approaches (5th ed.). London: Sage Publications.

Cesur, K., \& Ertas, A. (2018). Examining the prospective English teachers' pedagogical content knowledge: Canakkale case. International Journal of Progressive Education, 14(3), 123-140. https://doi.org/10.29329/ ijpe.2018.146.9

Cochran, K. (1993). Pedagogical content knowledge: Teachers' integration of subject matter, pedagogy, students, and learning environments. NARST. https://narst.org/research-matters/pedagogical-content-knowledge

Creswell, J. W. (2013). Qualitative inquiry \& research design: Choosing among five approaches (3rd ed.). London: Sage Publications.

Creswell, J.W., \& Poth C. N. (2016). Qualitative inquiry and research design: Choosing among five approaches (4th ed.). London: Sage Publications.

De Loreto, J., Demate, Jr. A., Dela Cruz, C., Periña, A., Paril, M., \& Esteves, J. (2019). A phenomenological study on the challenges and problems of new social studies teachers. International Journal of Social Sciences \& Educational Studies 6(2), 23-40. https://doi.org/10.23918/ijsses.v6i2p23

Evens, M., Elen, J., \& Depaepe, F. (2015). Developing pedagogical content knowledge: Lessons learned from intervention studies. Education Research International. https://doi.org/10.1155/2015/790417

Faisal, F. (2015). Pedagogical content knowledge in Indonesian English language teaching. Asia Pacific Journal of Multidisciplinary Research, 3(5), 103-110. http://www.apjmr.com/wp-content/uploads/2016/01/ APJMR-2015-3.5.2.14.pdf

Fuster Guillen, D. E. (2019). Qualitative research: Hermeneutical phenomenological method. Journal of Educational Psychology, 7(1), 217-229. http://dx.doi.org/10.20511/pyr2019.v7n1.267

Geng, C. (2017). On the teaching innovation of business English teaching: A study on multimodal communicative competence of ethnic universities. Theory and Practice in Language Studies, 7(4), pp.322-326. http://dx.doi. org/10.17507/tpls.0704.11

Guerriero, S. (2014). Teachers' pedagogical knowledge and the teaching profession: Background report and project objectives. Organization for Economic Cooperation and Development.

Guiyu, D., \& Yang, L. (2016). An empirical study on business English teaching and development in China: A needs analysis approach. Canadian Center of Science and Education, 6(2). http://dx.doi.org/10.5539/hes.v6n2p142

Hyde, C. (2013). Task-based language teaching in the business English classroom. http://digital.library.wisc. edu/1793/65453

James, N., \& Busher, H. (2009). Online interviewing. London: Sage Publications.

Jones, A., \& Moreland, J. (2015). Considering pedagogical content knowledge in the context of research on teaching: An example from technology. Waikato Journal of Education, 9. 65-76. https://doi.org/10.15663/wje. v20i3.224

Katsumura, M. (2011). Fear for jobs ignites "English crisis" in Japan. Reuters. https://www.reuters.com/article/usjapan-english/fear-for-jobs-ignites-english-crisis-in-japan-idUSTRE78L1AR20110922

Kultsum, U. (2017). The concept of pedagogical content knowledge (PCK): Recognizing the English teachers' competencies in Indonesia. Advances in Social Science, Education and Humanities Research, 134, 55-59. https://doi.org/10.2991/icirad-17.2017.11

Lincoln, Y.S., \& Guba, E.G. (1985). Naturalistic inquiry. Sage Publications.

Liu, L. (2016). English teaching model research based on network MOOC. Paper presented at the International Conference on Smart City and Systems Engineering. https://doi.org/10.1109/ICSCSE.2016.0058

Loughran J., Berry A., \& Mulhall P. (2012). Pedagogical content knowledge. Understanding and developing Science teachers' pedagogical content knowledge. Professional Learning, 12, 7-14. https://doi.org/10.1007/978-946091-821-6_2

Lyu, R. F., Akinnola, I. F., Oredein, A. O., \& Wei, R. (2021). An Investigation into pedagogical content knowledge (PCK): Teachers' views on knowledge. Teacher Education and Curriculum Studies, 6(2), 41. https://doi. org/10.11648/j.tecs.20210602.11

Melo, L., Canada, F., Gonzales-Gomes, D., \& Su Jeong, J. (2020). Exploring pedagogical content knowledge (PCK) of physics teachers in a Colombian secondary school. Education Sciences, 10, 362. https://doi.org/10.3390/ educsci10120362

Michaud, C. (2012). English the preferred language for world business: Poll. Reuters. https://www.reuters.com/ article/us-language-idUSBRE84F0OK20120516

Mihaescu, C. (2013). Current issues in teaching business English to university students. Knowledge Horizons, 5(1).

Nind, M. (2020). A new application for the concept of pedagogical content knowledge: Teaching advanced social science research methods. Oxford Review of Education. https://doi.org/10.1080/03054985.2019.1644996

Patton, M. Q. (2014). Qualitative research and evaluation methods (4th ed.). Sage Publications. 
Peng, W. (2013). Examining pedagogical content knowledge (PCK) for business English teaching: Concept and model. Polyglossia, 25, 83-94.

Pientka, V. (2012). A phenomenological study of teacher/mentors' pedagogical content knowledge [Doctoral dissertation, Northern Illinois University]. ProQuest. https://www.proquest.com/docview/1024733417

Podboj, M. (2013). Discourse-oriented approach to business English: Linking language in use and business context. ResearchGate.

Ratislavova, K., \& Ratislav, J. (2014). Asynchronous email interview as a qualitative research method in the humanities. Human Affairs, 24. 452-460. https://doi.org/10.2478/s13374-014-0240-y

Romanowski, P. (2015). Revisiting the concept of communication in business English. Some implications on teaching communicative skills. Lingwistyka Stosowana - Applied Linguistics - Angewandte Linguistik. 13, 65-76.

Shulman, L. S. (1986). Those who understand: Knowledge growth in teaching. Educational Researcher, 15(2), 4-14. https://doi.org/10.3102/0013189X015002004

Smith, J. A., Flowers, P., \& Larkin, M. (2021). Interpretative phenomenological analysis: Theory, method, and research. London: Sage Publications.

Solis, A. (2009). Pedagogical content knowledge: What matters most in the professional learning of content teachers in classrooms with diverse student populations? Intercultural Development Research Association. https:// www.idra.org/resource-center/pedagogical-content-knowledge/

Taylor, S. J., Bogdan, R., \& DeVault, M. (2015). Introduction to qualitative research methods: A guidebook and resource. John Wiley \& Sons.

Van Manen, M. (2016). Researching lived experience: Human science for an action sensitive pedagogy. Routledge.

Van Manen, M. (2007). Phenomenology of practice. Phenomenology \& Practice 1(1), p.11-30. https//doi. org/10.29173/pandpr19803

Wu, P., Yu, S., \& Zhang, L. (2019). The function and integration of components of pedagogical content knowledge (PCK) in classroom teaching: A case study of business English teachers. Educational Studies. https//doi.org/1 $0.1080 / 03055698.2018 .1509770$

$\mathrm{Xi}, \mathrm{Y}$. (2018). Research on the implications of business English teaching on bilingual courses in business communication. Education, Sustainability \& Society (ESS), 1(1), 11-13. https://doi.org/10.26480/ ess.01.2018.11.13

Zhang, Z. (2013). Identities in needs analysis for business English students. ESP Today, 1(1), pp.26-24.

\section{Correspondence:}

ANA MARIEL ABION MORENO

MAA4831@dlsud.edu.ph

https://orcid.org/0000-0001-5838-0550

CONSTANTINO T. BALLENA*

constantinoballena@gmail.com

tballena@dlsud.edu.ph

https://orcid.org/0000-0002-8772-0881

*Corresponding Author 